\title{
Development of Wind Loading Maps for Sri Lanka for use with Different Wind Loading Codes
}

\author{
W. L. S. Maduranga and C. S. Lewangamage
}

Abstract: It was more than 39 years ago that Sri Lanka last established a wind loading map after the severe cyclone that struck the country in 1978. It is strongly believed that statistical methods had not been used in developing this wind loading map. Hence, the map can either overestimate or underestimate the wind speeds at least in some regions of the country. Therefore, an updated map which suits the changing climate patterns experienced in the country has become a necessity. In Sri Lanka, different wind codes are being used when designing structures to withstand wind actions. Moreover, there is no wind loading map that is suitable for use with Eurocode 1.

This paper presents the development of wind loading maps for Sri Lanka using wind data obtained from 24 weather stations. The data used were the monthly maximum 3-minute average wind speeds, and monthly instantaneous maximum wind speeds, recorded over a period of about 35 and 5 years respectively. An extreme value distribution called Gringorten method was used to predict the extreme wind speeds. Maps demarcating 3-second gust and 10-minute average basic wind speeds for Sri Lanka were developed for different return periods.

Keywords: $\quad$ Basic wind speeds, Wind loading map for Sri Lanka, Gringorten Method, Eurocode 1

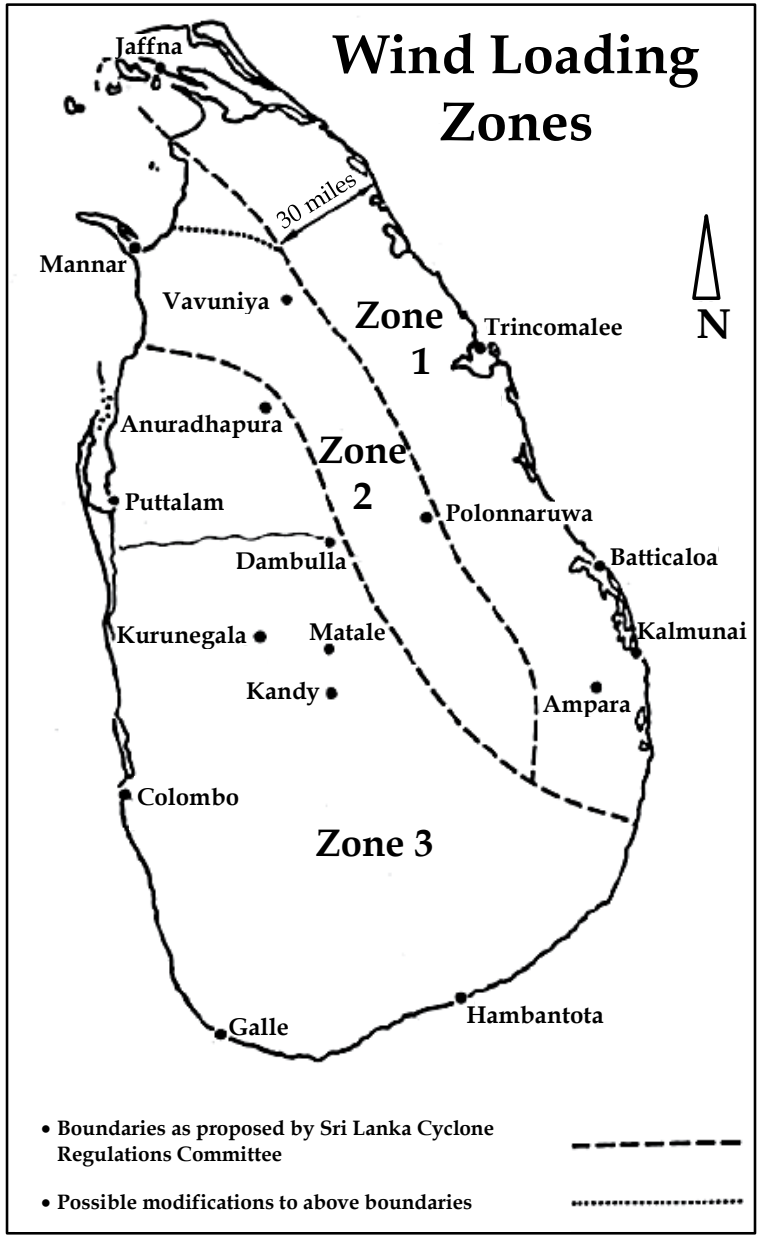

Figure 1 - Existing wind loading zones of Sri Lanka [2]

\section{Introduction}

Wind load is one of the major lateral loads acting on civil engineering structures. An accurate estimation of the wind load is necessary in the design of structures to make them safe and economical.

It was more than 39 years ago that Sri Lanka last established a wind loading map. This map shown in Figure 1 would have been developed based on the damage pattern observed during the severe cyclone that struck the country in the year 1978 and the Indian wind loading map of that particular period [1]. Hence, it has not been based on any statistical method or observed wind data. There are few ambiguities in this map. In general, two wind speed contours cannot intersect each other. In the Ampara region, wind speed contours have become discontinuous. As a result, Zone 3 meets Zone

Eng. W. L. S. Maduranga, AMIE(SL),B.Sc. Eng. (Hons) (Moratuwa), Lecturer (Probationary), Division of Civil

Engineering Technology, Institute of Technology, University of Moratuwa, Sri Lanka.

Email:wlsanjaya@gmail.com

ORCID ID: http://orcid.org/0000-0002-8293-4864

Eng. (Dr.) C. S. Lewangamage, MIE(SL), C. Eng., MSSE (SL), B.Sc. Eng. (Hons) (Moratuwa), M.Eng. (Tokyo), Ph.D (Tokyo), Senior Lecturer, Department of Civil Engineering, University of Moratuwa, Sri Lanka.

Email: cslewangamage@gmail.com

ORCID ID: https://orcid.org/0000-0002-0373-5307 
1. Therefore, the 3-second gust wind speed for normal structures in the region abruptly increases from $33 \mathrm{~ms}^{-1}$ to $49 \mathrm{~ms}^{-1}$ (Table 1), which is an increase of almost $50 \%$. In addition, the long-term changes of wind patterns due to global and local climate changes need to be considered.

Table 1 - Basic wind speeds of different wind loading zones in Sri Lanka [2]

\begin{tabular}{|c|c|c|}
\hline \multirow{2}{*}{$\begin{array}{c}\text { Wind } \\
\text { loading } \\
\text { zone }\end{array}$} & \multicolumn{2}{|c|}{$\begin{array}{c}\text { 3-Second gust speed for 50 } \\
\text { year return period (ms } \mathbf{~}^{\mathbf{1}}\end{array}$} \\
\cline { 2 - 3 } & $\begin{array}{c}\text { Post disaster } \\
\text { structures }\end{array}$ & $\begin{array}{c}\text { Normal } \\
\text { structures }\end{array}$ \\
\hline Zone 1 & 54 & 49 \\
\hline Zone 2 & 47 & 42 \\
\hline Zone 3 & 38 & 33 \\
\hline
\end{tabular}

Nandalal and Abeyruwan (2010) [3] made an attempt to demarcate wind loading zones in Sri Lanka. Figure 2 shows the wind loading map proposed by them, a map completely different from the existing map. The difference between the two maps is that the zone marked as critical in the existing map has been identified as less critical in the proposed map. This could be unacceptable for the engineering community since the north-eastern and eastern coasts of the country are the regions that were mostly affected by the cyclonic events in the past. Hence, the proposed map had not been accepted and is not being used.

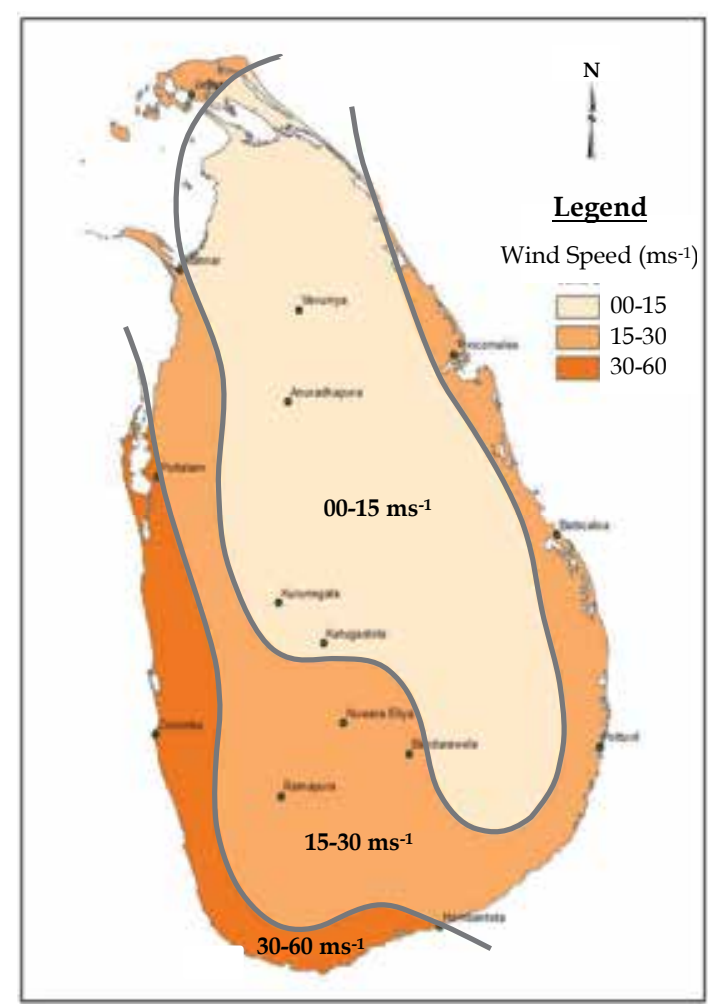

Figure 2 - Wind Zoning Map proposed by Nandalal and Abeyruwan (2010) [3]
The map proposed by Nandalal et al. [3], is based on wind data recorded only at 15 of the 23 weather stations in Sri Lanka. The data had been collected over a period of about 10 years. The data obtained from some stations such as Katugastota and Kurunegala, have been recorded over a period of less than 5 years. In general, to predict the extreme wind speeds for a return period of 50 years, data of at least 25 years need to be used.

In this map, wind speed between any two zones can vary from $15 \mathrm{~ms}^{-1}$ to $30 \mathrm{~ms}^{-1}$ which can be considered as a very low resolution. In urban regions such as the south-western coast, the wind loads could be much higher as the basic wind speed is about $60 \mathrm{~ms}^{-1}$. Furthermore, it was identified that some of the important wind data for the period considered (generally around 30 to 50 daily wind speeds per year and cyclonic data) were missing or were not considered during the analysis.

Because of these undesirable aspects noted in both the existing and the proposed wind loading maps of Sri Lanka, an updated wind loading map has become a necessity.

In Sri Lanka, engineers use different standards to calculate wind actions. These standards can be as old as CP 3: Chapter V-2 or as new as AS/NZS 1170.2 or EN 1991-1-4. Different codes of practice use different averaging times to define the basic wind speeds at a given location. CP 3: Chapter V-2 and AS/NZS 1170.2 consider 3-second gust wind speed as the basic wind speed while Eurocode 1 considers 10minute average wind speed as the basic wind speed. However, the existing wind loading map of Sri Lanka has considered only the 3-second gust wind speed as the basic wind speed. Therefore, the 3-second gust has to be converted to other averaging times by using conversion factors which will depend on terrain variations. However, the direct conversion of 3second gust wind speeds to other averaging times would not be accurate because in Sri Lanka the terrain over a given zone can change considerably.

According to the literature, the basic wind speed map for Oman was developed by Alnuaimi et al. [4] using hourly mean wind speed records obtained from 40 metrological stations. The period over which the wind speeds had been continuously recorded had been from 4 to 37 years. The maximum annual hourly mean wind data and the maximum 
monthly hourly mean wind data were analyzed using both Gumbel and Gringorten methods. Both methods have given almost similar results with Gumbel method giving slightly higher values. Finally, the Gumbel method had been adopted to predict the basic wind speeds.

More recently, Lakshmanan et al. [5] has updated a basic wind speed map for India using long-term wind speed data obtained from 70 metrological stations. The daily gust wind data were processed to find the annual maximum wind speeds for each site. Gumbel method was adopted to derive the extreme wind speeds.

This paper presents a detailed study carried out to develop basic wind speed contours and wind loading zones for Sri Lanka for different averaging times and return periods.

\section{Data Collection}

The Department of Meteorology, Sri Lanka has been recording wind speeds and directions at a $10 \mathrm{~m}$ above ground level at 23 major weather stations, all of which were on almost flat terrain. At the stations wind data are manually measured and recorded in rough observation books (ROB) as 3-minute average wind speeds measured once in every 3 hours ( 8 times per day).

Since the year 2009, automatic weather stations (AWS) have been introduced to measure wind speeds in Sri Lanka. These stations can operate continuously and their readings are highly accurate. The continuously measured instantaneous wind speeds can be used to obtain the maximum instantaneous wind speed of a particular month. A sample data recording sheet of an AWS is given in Table 2.

Table 2 - A Sample Data Sheet of an automatic weather station (AWS) in Sri Lanka

\begin{tabular}{|c|c|c|c|c|c|}
\hline \multicolumn{6}{|c|}{ Station: Anuradhapura, Location: $\left(0820^{\prime} \mathrm{N}, 8^{\left.8023^{\prime} \mathrm{E}\right)}\right.$} \\
\hline $\begin{array}{l}\text { Month } \\
\text { and year }\end{array}$ & $\begin{array}{c}\text { Average } \\
\text { wind speed } \\
\left(\mathrm{ms}^{-1}\right)\end{array}$ & $\begin{array}{l}\text { Average } \\
\text { wind } \\
\text { direction }\left({ }^{\circ}\right)\end{array}$ & $\begin{array}{l}\text { Maximum } \\
\text { instant. wind } \\
\text { speed }\left(\mathrm{ms}^{-1}\right)\end{array}$ & $\begin{array}{l}\text { Maximum } \\
\text { instant. wind } \\
\text { direction }\left({ }^{\circ}\right)\end{array}$ & $\begin{array}{l}\text { Maximum instant. } \\
\text { wind speed } \\
\text { occurred at }\end{array}$ \\
\hline Jan-2010 & 1.4 & 073 & 13.8 & 343 & $2010 / 01 / 22,11: 40$ \\
\hline Feb-2010 & 1.3 & 071 & 9.6 & 300 & $2010 / 02 / 09,14: 43$ \\
\hline Mar-2010 & 1.2 & 127 & 9.3 & 029 & $2010 / 03 / 22,19: 28$ \\
\hline Apr-2010 & 1.2 & 186 & 13.2 & 113 & $2010 / 04 / 16,17: 37$ \\
\hline May-2010 & 2.1 & 211 & 14.9 & 317 & $2010 / 05 / 27,05: 59$ \\
\hline Jun-2010 & 2.7 & 227 & 14.7 & 270 & $2010 / 06 / 24,15: 24$ \\
\hline Jul-2010 & 2.5 & 219 & 14.5 & 270 & $2010 / 07 / 01,12: 19$ \\
\hline Aug-2010 & 2.5 & 223 & 13.3 & 252 & $2010 / 08 / 30,14: 15$ \\
\hline
\end{tabular}

Table 3 - Details of the major weather stations of the Department of Meteorology, Sri Lanka

\begin{tabular}{|l|c|c|c|c|}
\hline \multicolumn{1}{|c|}{ Major weather station } & Period & Data availability in months & Longitude (o) & Latitude (o) \\
\hline Anuradhapura & $1978-2015$ & 394 & 80.415 & 8.334 \\
\hline Bandarawela & $1980-2015$ & 425 & 80.985 & 6.839 \\
\hline Batticaloa & $1976-2015$ & 453 & 81.681 & 7.705 \\
\hline Colombo & $1976-2016$ & 455 & 79.872 & 6.905 \\
\hline Galle & $1981-2009$ & 197 & 80.214 & 6.030 \\
\hline Hambantota & $1981-2014$ & 388 & 81.129 & 6.122 \\
\hline Jaffna & $1976-2015$ & 236 & 80.033 & 9.694 \\
\hline Katunayake & $1988-2015$ & 334 & 79.878 & 7.167 \\
\hline Maha Illuppallama & $1978-2015$ & 357 & 80.468 & 8.111 \\
\hline Mannar & $1978-2015$ & 395 & 79.908 & 8.987 \\
\hline Nuwara Eliya & $1980-2015$ & 429 & 80.779 & 6.970 \\
\hline Pottuvil & $1983-2015$ & 308 & 81.833 & 6.883 \\
\hline Puttalam & $1981-2015$ & 405 & 79.842 & 8.027 \\
\hline Rathmalana & $1981-1985$ & 056 & 79.887 & 6.819 \\
\hline Ratnapura & $1993-2015$ & 247 & 80.383 & 6.717 \\
\hline Trincomalee & $1976-2015$ & 327 & 81.242 & 8.576 \\
\hline Vavuniya & $1996-2015$ & 223 & 80.502 & 8.745 \\
\hline
\end{tabular}


Table 4 - Details of automatic weather stations (AWS) of the Department of Meteorology, Sri Lanka

\begin{tabular}{|l|c|c|c|c|}
\hline Automatic weather station & Period & Data availability in months & Longitude (o) & Latitude (o) \\
\hline Anuradhapura & $2009-2015$ & 63 & 80.415 & 8.334 \\
\hline Badulla & $2009-2015$ & 62 & 81.049 & 6.983 \\
\hline Bandarawela & $2009-2015$ & 50 & 80.985 & 6.839 \\
\hline Batticaloa & $2009-2011$ & 13 & 81.681 & 7.705 \\
\hline Colombo & $2009-2016$ & 84 & 79.872 & 6.905 \\
\hline Deniyaya & $2009-2015$ & 56 & 80.550 & 6.317 \\
\hline Hambantota & $2009-2015$ & 45 & 81.129 & 6.122 \\
\hline Katugastota & $2009-2015$ & 69 & 80.627 & 7.334 \\
\hline Katunayake & $2009-2015$ & 35 & 79.878 & 7.167 \\
\hline Kurunegala & $2009-2015$ & 64 & 80.353 & 7.480 \\
\hline Maha Illuppallama & $2009-2015$ & 52 & 80.468 & 8.111 \\
\hline Mannar & $2011-2015$ & 20 & 79.908 & 8.987 \\
\hline Monaragala & $2009-2015$ & 51 & 81.316 & 6.835 \\
\hline Nuwara Eliya & $2009-2015$ & 63 & 80.779 & 6.970 \\
\hline Polonnaruwa & $2009-2012$ & 21 & 81.050 & 7.913 \\
\hline Pottuvil & $2011-2015$ & 33 & 81.833 & 6.883 \\
\hline Puttalam & $2009-2015$ & 63 & 79.842 & 8.027 \\
\hline Rathmalana & $2009-2015$ & 59 & 79.887 & 6.819 \\
\hline Ratnapura & $2009-2014$ & 39 & 80.383 & 6.717 \\
\hline Tawalama & $2009-2014$ & 42 & 80.342 & 6.336 \\
\hline Vavuniya & $2009-2015$ & 31 & 80.502 & 8.745 \\
\hline
\end{tabular}

Some of the details of major weather stations and automatic weather stations of Sri Lanka are given in Tables 3 and 4 respectively. All the data for this study were obtained from the Department of Meteorology of Sri Lanka.

In some of the weather stations, the Beaufort scale has been used to measure wind speeds when their anemometers failed to function. Since it is a visual measurement of the wind speed, the values obtained will fully depend on the observer. Therefore, such data were not considered in this study.

\section{Methodology}

\subsection{Conversion between Instantaneous} Maximum Wind Speed and 3-Second Gust

As shown in Figure 3a, instantaneous maximum wind speed is the highest instantaneous wind speed recorded during a given time period. 3-second gust is the highest of the 3 second average wind speed recorded during a given time period as shown in Figure $3 b$.

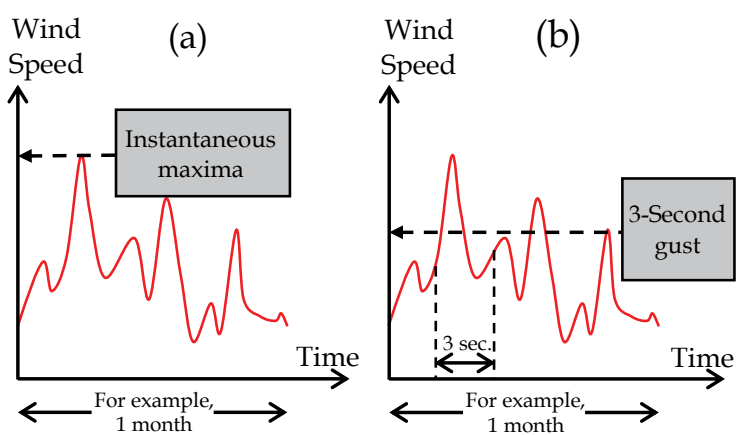

Figure 3 - Comparison between instantaneous maxima and 3-Second Gust

Hsu [6] developed a model that can be used to predict 3-second gusts and instantaneous maximum wind speeds using 1-minute sustained wind speeds as given in Equations (1) and (2) given below.

$U_{(3-s e c)}=U_{(1-\min )} \cdot(1+2 p)$
$U_{(\max )}=U_{(1-\min )} \cdot(1+3 p)$

where,

$U_{(3-\mathrm{sec})}=3$-second gust,

$U_{(\max )}=$ Maximum instantaneous wind speed,

$U_{(1-m i n)}=1$-Minute sustained wind speed,

$p \quad=$ Exponent of the power law of wind profile 
Exponent of the power law of wind profile (p) is a function of the surface roughness of the ground. If the value of ' $p$ ' near a weather station is known, an equation for 3-second gust can be derived using Equations (1) and (2) as given below.

$U_{(3-s e c)}=U_{(\max )} \cdot \frac{(1+2 p)}{(1+3 p)}$

Panofsky and Dutton [7] suggested Equation (4) given below to determine the value of ' $\mathrm{p}$ ' for a given terrain when the surface roughness value of the terrain is known.

$p=\frac{1}{\ln \left(\frac{Z}{Z o}\right)}$

where,

$p=$ Exponent of the power law of wind profile,

$Z=$ Height of wind measurement,

$Z_{o}=$ Roughness length

$Z_{o}$ depends on the nature of the ground as shown in Figure 4 [8]. Since the ground features of a complex terrain would not be uniformly distributed, the results would not be accurate, if the values for $Z_{0}$ mentioned in Figure 4 are used.

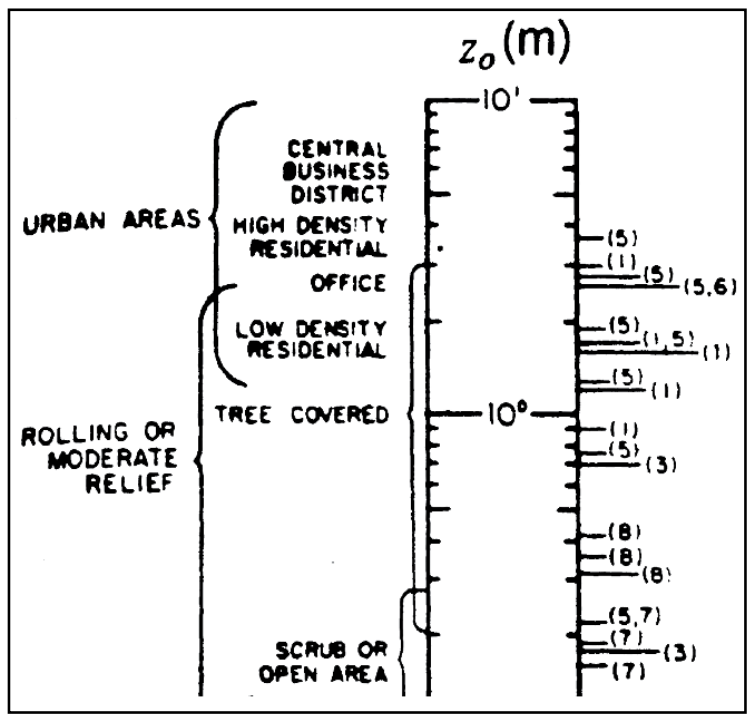

Figure 4 - Surface Roughness Lengths $\left(Z_{0}\right)[8]$

Hsu [6] has measured actual 3-second gust and instantaneous maximum wind speeds at 7 stations in USA to prove the accuracy of Equations (1) and (2). The obtained wind speeds are shown in Table 5.

The ' $p$ ' value of a particular location will depend on the nature of the surface obstacles and the surface roughness characteristics at the location. Since the 3-second gust and the instantaneous maximum wind speeds are known at the locations mentioned in Table 5, a back calculation can be carried out using Equation (5) and ' $p$ ' value found for each station.

Table 5 - $\mathrm{U}_{(3 \text {-sec) }}$ and $\mathrm{U}_{(\max )}$ measured by $\mathrm{Hsu}$ (2008) at selected stations in USA [6]

\begin{tabular}{|l|c|c|}
\hline \multicolumn{1}{|c|}{ Deployment site } & $\begin{array}{c}\text { Measured } \\
\mathbf{U}_{(\mathbf{3 - s e c})} \\
\text { (ms }^{-\mathbf{1}} \mathbf{n}\end{array}$ & $\begin{array}{c}\text { Measured } \\
\mathbf{U}_{(\mathbf{m a x})} \\
\mathbf{( m s}^{-1} \mathbf{)}\end{array}$ \\
\hline Vacherie, LA & 31.4 & 32.8 \\
\hline Slidell, LA & 38.5 & 44.6 \\
\hline Bay St. Louis, MS & 47.1 & 52.3 \\
\hline Anahuac, TX & 37.9 & 40.5 \\
\hline Winnie, TX & 38.6 & 40.7 \\
\hline Port Arthur, TX & 51.9 & 53.8 \\
\hline Orange, TX & 39.3 & 42.1 \\
\hline
\end{tabular}

$p=\frac{U_{(3-s e c)}-U_{(\max )}}{2 U_{(\max )}-3 U_{(3-s e c)}}$

' $p$ ' value for each weather station in Sri Lanka was estimated (Table 6) depending on their ground roughness characteristics and terrain conditions based on the study carried out by Hsu [6]. These values have been used to predict the 3-second gust wind speeds from the instantaneous maximum wind speeds recorded at AWS.

Table 6 - 'p' values calculated for each automatic weather station (AWS)

\begin{tabular}{|l|c|l|c|}
\hline Weather station & $\mathbf{p}$ & Weather station & $\mathbf{p}$ \\
\hline Anuradhapura & 0.09 & Mannar & 0.07 \\
\hline Badulla & 0.15 & Monaragala & 0.12 \\
\hline Bandarawela & 0.15 & Nuwara Eliya & 0.15 \\
\hline Batticaloa & 0.05 & Polonnaruwa & 0.09 \\
\hline Colombo & 0.15 & Pottuvil & 0.05 \\
\hline Deniyaya & 0.09 & Puttalam & 0.12 \\
\hline Hambantota & 0.05 & Rathmalana & 0.15 \\
\hline Katugastota & 0.15 & Ratnapura & 0.12 \\
\hline Katunayake & 0.07 & Tawalama & 0.09 \\
\hline Kurunegala & 0.12 & Vavuniya & 0.09 \\
\hline Maha Illuppallama & 0.09 & & \\
\hline
\end{tabular}

3.2 Conversion between 3-minute Average and 3-second Gust

The wind data recorded as 3-minute average wind speeds were converted to 3 -second gusts based on the recommendations of the World Meteorological Organization (WMO)which are indicated in Table 7 [9]. The gust conversion factors assigned for each weather station are listed in Table 8. 
Table 7 - WMO recommended wind speed conversion factors for tropical cyclonic conditions [9]

\begin{tabular}{|l|l|c|c|}
\hline \multicolumn{1}{|c|}{ Exposure at $+\mathbf{1 0 m}$} & $\begin{array}{c}\text { Gust conversion factor } \\
\text { from 3-minute average to } \\
\text { 3-second gust }\left(\mathbf{G}_{3,180}\right)\end{array}$ & $\begin{array}{c}\text { Gust conversion factor } \\
\text { from10-minute average to } \\
\text { 3-second gust }\left(\mathbf{G}_{3,600}\right)\end{array}$ \\
\hline In-land & Roughly open terrain & 1.58 & 1.66 \\
\hline Off-land & Offshore winds at a coastline & 1.44 & 1.52 \\
\hline Off-sea & Onshore winds at a coastline & 1.31 & 1.38 \\
\hline At-sea & $>$ 20km offshore & 1.17 & 1.23 \\
\hline
\end{tabular}

Table 8 - Gust conversion factors assigned for weather stations relevant to ROB wind data

\begin{tabular}{|l|c|}
\hline Weather station & $\begin{array}{c}\text { Gust conversion factor } \\
\text { from 3-minute average to } \\
\text { 3-second gust }\left(\mathbf{G}_{3,180}\right)\end{array}$ \\
\hline Anuradhapura & 1.58 \\
\hline Bandarawela & 1.58 \\
\hline Batticaloa & 1.31 \\
\hline Colombo & 1.58 \\
\hline Galle & 1.31 \\
\hline Hambantota & 1.44 \\
\hline Jaffna & 1.58 \\
\hline Katunayake & 1.44 \\
\hline Maha Illuppallama & 1.58 \\
\hline Mannar & 1.58 \\
\hline Nuwara Eliya & 1.58 \\
\hline Pottuvil & 1.44 \\
\hline Puttalam & 1.58 \\
\hline Rathmalana & 1.58 \\
\hline Ratnapura & 1.58 \\
\hline Trincomalee & 1.31 \\
\hline Vavuniya & 1.58 \\
\hline
\end{tabular}

\subsection{Determination of Extreme Wind} Speeds

The extreme wind speeds for several return periods $(5,10,50 \& 100$ years $)$ at each weather station were predicted using Gringorten method. The Gringorten method is a more fitting and unbiased method than the Gumbel method for extreme wind speed predictions [10]. Linear regression method was used to estimate the best linear prediction for each station.

The 3-minute average wind speeds were recorded in Rough Observation Books (ROB) only once in every 180 minutes (3 hours). This means that the monthly maximum wind speeds that were measured have actually been recorded over an equivalent period of half a day (30 days $\times 3 / 180$ ). In order to complete an actual monthly record, 60 such half a day periods had to be considered.
As the initial step of using the Gringorten method, all of the data items $(\mathrm{N})$ were sorted in the descending order and the largest N/60 items were taken to determine the equivalent monthly maxima. It was assumed that the recorded 3-minute average wind speeds were unbiased samples from their respective domains. This way the errors that could occur as a result of recording discontinuous data could be avoided. Weather stations that did not contain sufficient wind data were excluded from the analysis.

Figures 5, 6 and 7 show few samples of the graphs that were plotted to predict extreme wind speeds using the Gringorten method.

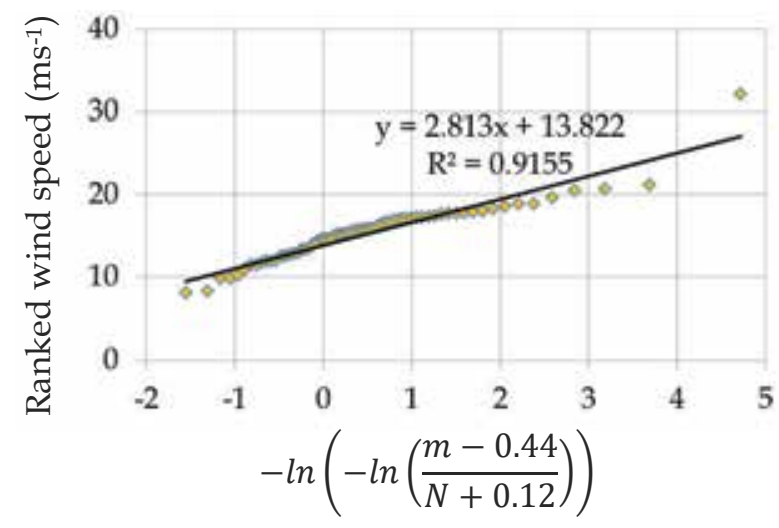

Figure 5 - Application of Gringorten Method for wind data at the Anuradhapura Station

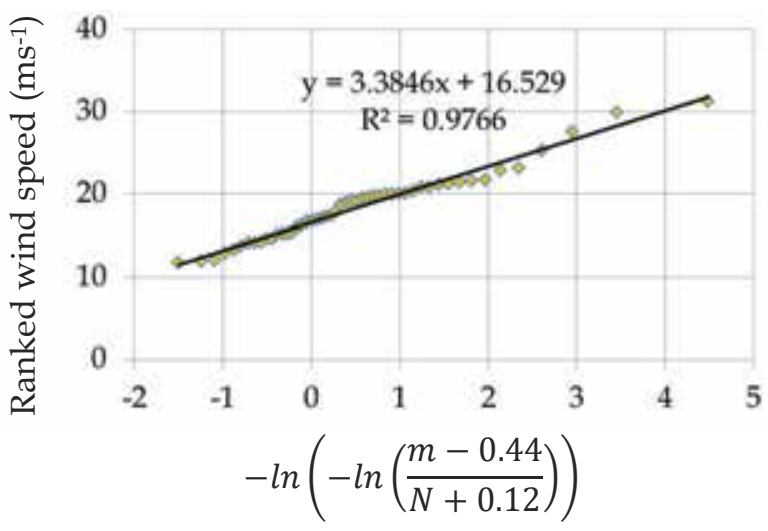

Figure 6 - Application of Gringorten Method for wind data at the Bandarawela Station 


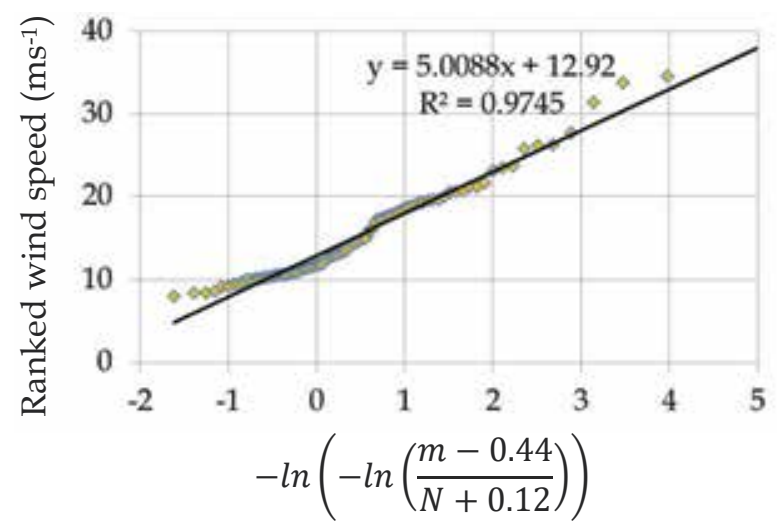

Figure 7 - Application of Gringorten Method for wind data at the Colombo Station

The extreme wind speed values predicted for each station are given in Table 9. Gust conversion factors for converting 10-minute average to 3-second gust $\left(\mathrm{G}_{3,600}\right)$ were assigned for each station depending on their terrain roughness values.

\section{Results and Discussion}

The extreme wind speed values calculated were used to develop wind speed contours for $3 \mathrm{sec}$ gust and 10-minute average wind speeds. The maps generated using Surfer 8 software package are shown in Figures 8 and 9. To interpolate values between the weather stations, Kriging interpolation technique was used.

For the convenience of the users, three major wind loading zones have been proposed as shown in Figure 10. Based on the pattern of the wind contours, basic wind speed values for each zone (in 3-second gust and 10-minute average) have been assigned for several return periods. The final wind speed value for each zone for different return periods is given in Table 10. When the 10-minute mean wind speed for a 50 year return period is used with Eurocode 1, the altitude correction factor could be used as 1.0 since terrain altitude has already been incorporated into the analysis.

Table 9 - Extreme wind speeds predicted at each station for different return periods

\begin{tabular}{|c|c|c|c|c|c|c|c|c|c|}
\hline \multirow{4}{*}{ Weather station } & \multirow{4}{*}{$\begin{array}{c}\text { Gust } \\
\text { conversion } \\
\text { factor } \\
\left(\mathrm{G}_{3,600}\right)[9]\end{array}$} & \multicolumn{8}{|c|}{ Predicted extreme wind speeds (ms') } \\
\hline & & \multicolumn{4}{|c|}{ 3-second gust } & \multirow{2}{*}{\multicolumn{4}{|c|}{$\begin{array}{l}\text { 10-minute average } \\
\text { Return period (years) }\end{array}$}} \\
\hline & & \multicolumn{4}{|c|}{ Return period (years) } & & & & \\
\hline & & 5 & 10 & 50 & 100 & 5 & 10 & 50 & 100 \\
\hline Anuradhapura & 1.66 & 24.9 & 26.9 & 31.4 & 33.3 & 15.0 & 16.2 & 18.9 & 20.0 \\
\hline Badulla & 1.66 & 27.8 & 30.3 & 36.1 & 38.7 & 16.7 & 18.3 & 21.8 & 23.3 \\
\hline Bandarawela & 1.66 & 30.6 & 32.7 & 37.8 & 39.9 & 18.4 & 19.7 & 22.7 & 24.0 \\
\hline Batticaloa & 1.38 & 42.0 & 46.3 & 56.3 & 60.6 & 30.5 & 33.6 & 40.8 & 43.9 \\
\hline Colombo & 1.66 & 26.3 & 28.3 & 32.8 & 34.7 & 15.8 & 17.0 & 19.8 & 20.9 \\
\hline Deniyaya & 1.66 & 21.8 & 24.6 & 30.9 & 33.5 & 13.1 & 14.8 & 18.6 & 20.2 \\
\hline Galle & 1.38 & 28.7 & 30.7 & 35.3 & 37.3 & 20.8 & 22.3 & 25.6 & 27.0 \\
\hline Hambantota & 1.52 & 34.9 & 36.9 & 41.3 & 43.2 & 23.0 & 24.2 & 27.2 & 28.4 \\
\hline Jaffna & 1.66 & 25.6 & 26.5 & 28.6 & 29.4 & 15.4 & 16.0 & 17.2 & 17.7 \\
\hline Katugastota & 1.66 & 23.2 & 24.3 & 26.9 & 28.0 & 14.0 & 14.7 & 16.2 & 16.8 \\
\hline Katunayake & 1.52 & 30.5 & 31.3 & 33.2 & 34.0 & 20.1 & 20.6 & 21.8 & 22.4 \\
\hline Kurunegala & 1.66 & 28.8 & 30.2 & 33.6 & 35.1 & 17.3 & 18.2 & 20.3 & 21.2 \\
\hline Maha Illuppallama & 1.66 & 34.9 & 36.7 & 40.9 & 42.7 & 21.0 & 22.1 & 24.7 & 25.8 \\
\hline Mannar & 1.66 & 34.5 & 36.1 & 39.8 & 41.4 & 20.8 & 21.7 & 24.0 & 24.9 \\
\hline Monaragala & 1.66 & 21.5 & 23.5 & 28.3 & 30.3 & 13.0 & 14.2 & 17.0 & 18.2 \\
\hline Nuwara Eliya & 1.66 & 34.1 & 36.1 & 40.5 & 42.5 & 20.6 & 21.7 & 24.4 & 25.6 \\
\hline Polonnaruwa & 1.66 & 23.2 & 24.6 & 27.7 & 29.0 & 14.0 & 14.8 & 16.7 & 17.5 \\
\hline Pottuvil & 1.52 & 24.8 & 26.5 & 30.4 & 32.1 & 16.3 & 17.4 & 20.0 & 21.1 \\
\hline Puttalam & 1.66 & 24.3 & 25.7 & 28.9 & 30.3 & 14.7 & 15.5 & 17.4 & 18.2 \\
\hline Rathmalana & 1.66 & 26.4 & 27.9 & 31.4 & 32.9 & 15.9 & 16.8 & 18.9 & 19.8 \\
\hline Ratnapura & 1.66 & 40.6 & 41.7 & 44.0 & 45.1 & 24.5 & 25.1 & 26.5 & 27.1 \\
\hline Tawalama & 1.66 & 23.9 & 26.3 & 31.9 & 34.3 & 14.4 & 15.8 & 19.2 & 20.7 \\
\hline Trincomalee & 1.38 & 42.2 & 45.5 & 53.2 & 56.5 & 30.6 & 33.0 & 38.6 & 41.0 \\
\hline Vavuniva & 1.66 & 22.0 & 23.9 & 28.3 & 30.2 & 13.3 & 14.4 & 17.1 & 18.2 \\
\hline
\end{tabular}




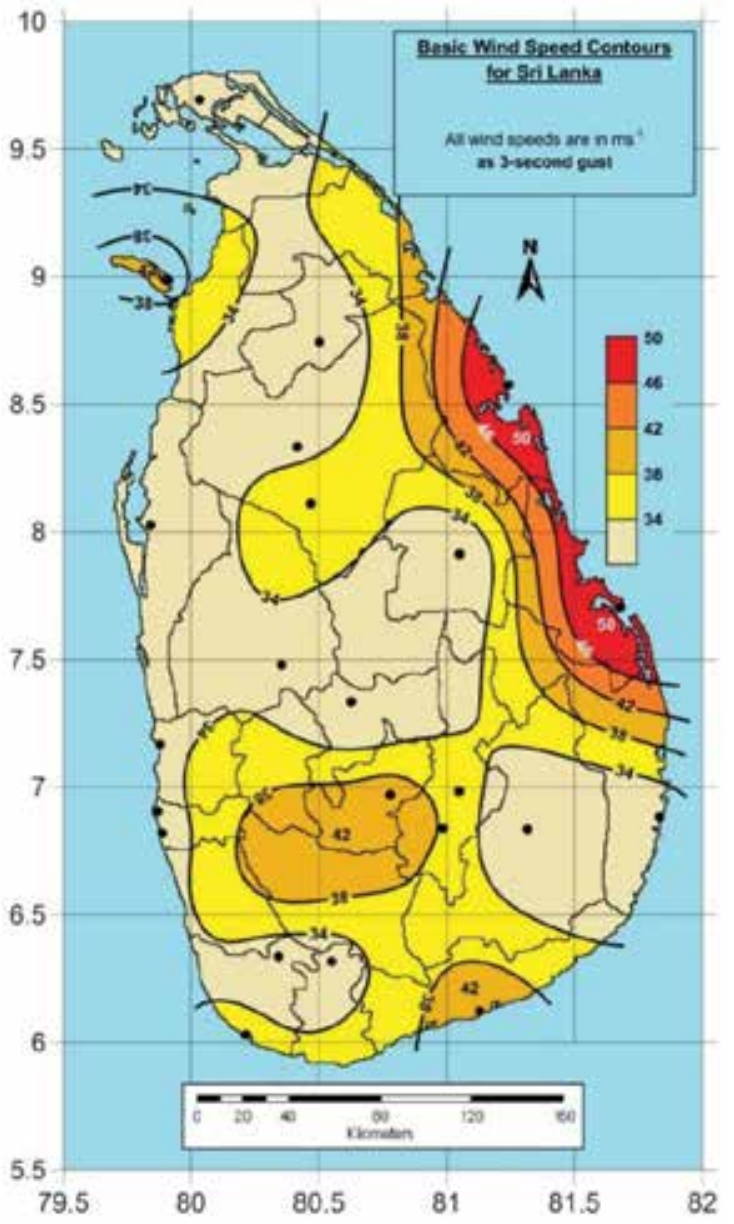

Figure 8 - Basic wind speed contours for Sri Lanka in 3-second gust wind speeds

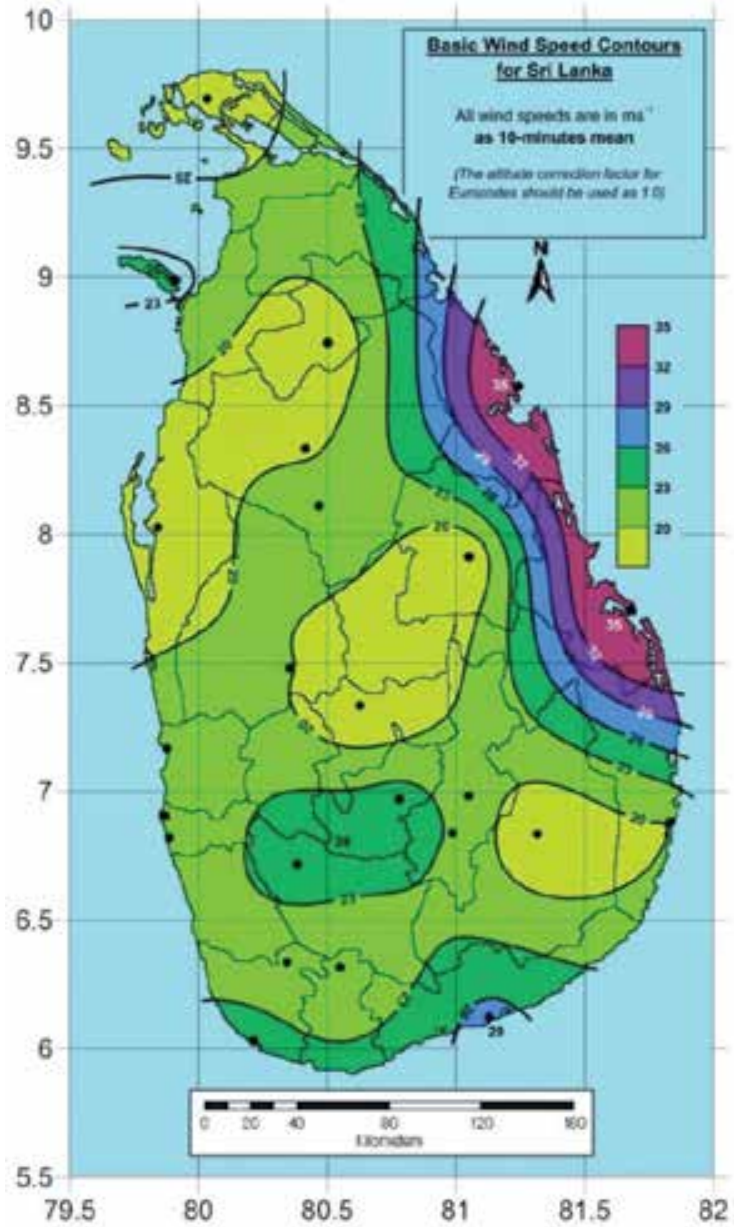

Figure 9 - Basic wind speed contours for Sri Lanka in 10-minute mean wind speeds

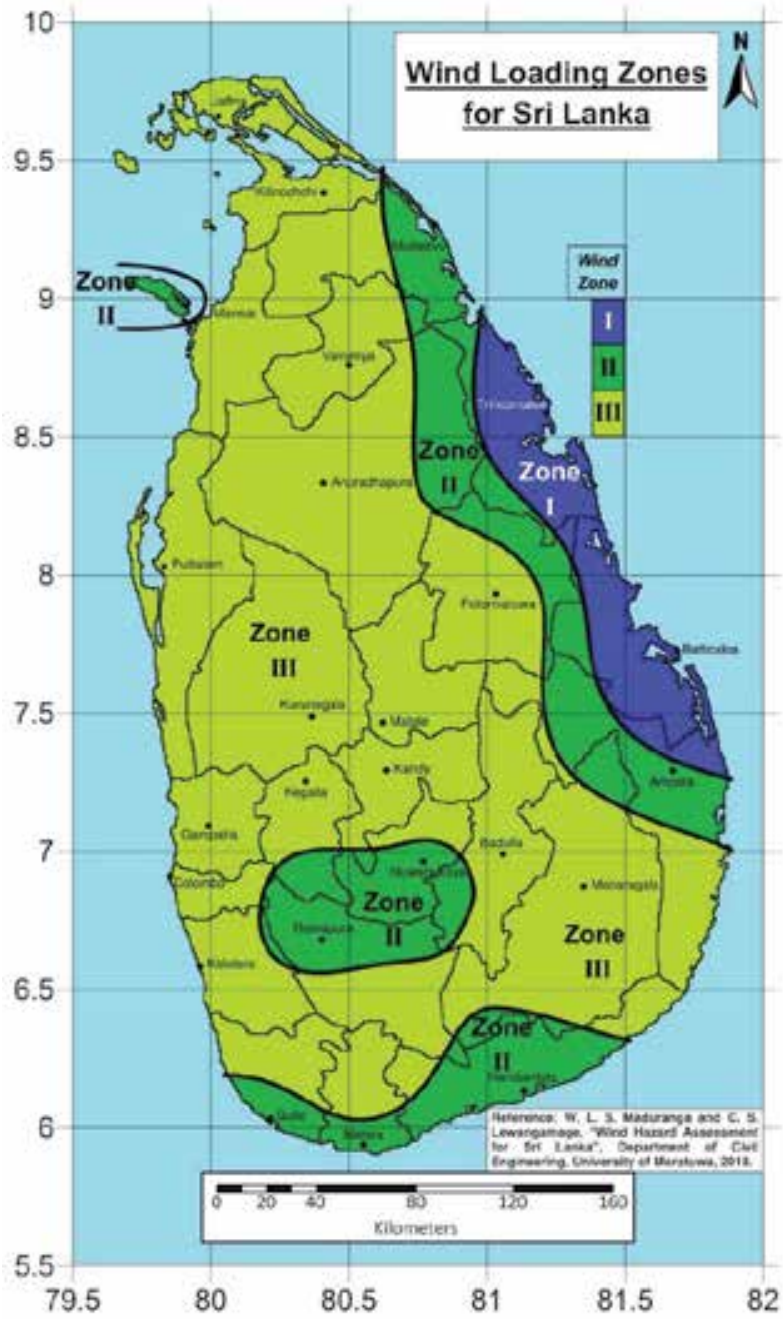

Figure 10 - Wind Loading Zones proposed for Sri Lanka

Table 10 - Proposed Basic Wind Speeds for Each Wind Loading Zone

\begin{tabular}{|c|c|c|c|c|c|c|c|c|}
\hline \multirow{2}{*}{$\begin{array}{c}\text { Wind } \\
\text { loading } \\
\text { zone }\end{array}$} & \multicolumn{4}{|c|}{ Basic wind speed (ms ${ }^{\mathbf{1}}$ ) } \\
\cline { 2 - 9 } & \multicolumn{3}{|c|}{$\begin{array}{c}\text { 3-Second gust } \\
\text { Return period } \\
\text { (years) }\end{array}$} & \multicolumn{4}{c|}{$\begin{array}{c}\text { Return period } \\
\text { (years) }\end{array}$} \\
\cline { 2 - 9 } & 5 & 10 & $\mathbf{5 0}$ & 100 & 5 & 10 & $\mathbf{5 0}$ & 100 \\
\hline I & 40 & 43 & $\mathbf{5 0}$ & 54 & 28 & 31 & $\mathbf{3 5}$ & 38 \\
\hline II & 34 & 36 & $\mathbf{4 2}$ & 45 & 23 & 25 & $\mathbf{2 9}$ & 31 \\
\hline III & 32 & 34 & $\mathbf{3 8}$ & 40 & 20 & 21 & $\mathbf{2 3}$ & 24 \\
\hline
\end{tabular}

\section{Conclusions}

The wind loading map of Sri Lanka that is used at present had not been developed using any statistical method or past wind data.

The wind loading map proposed for Sri Lanka in this paper was developed based on wind data collected from 24 weather stations located throughout the country. Wind data of about 35 years were used. 
The map generated has a pattern similar to the pattern in the map that is being used at present. The basic wind speeds stated in the map are slightly higher than the values stated in the existing map.

The proposed basic wind speeds can be used with CP 3 Chapter V-2, AS/NZS 1170.2 and Eurocode 1 which can be considered as the most used wind codes in Sri Lanka.

\section{Acknowledgement}

This research was supported by the Senate Research Council Grant Number SRC/LT/2016/01 of University of Moratuwa. The authors wish to express their special thanks to the Department of Meteorology of Sri Lanka and Prof. K.D.W. Nandalal for providing wind data required for this study.

\section{References}

1. Lewangamage,C. S., \& Jayasinghe, M. T. R., "Report on recent development of wind code in Sri Lanka", Proc., Regional Harmonization of Wind Loading and Wind Environmental Specifications in Asia-Pacific Economies $\quad(A P E C-W W), 7^{\text {th }}$ Workshop, Vietnam, 2012.

2. Ministry of Local Government, Housing and Construction, "Design of Buildings for Higher Wind - Sri Lanka", Sri Lanka, 1980, pp. 7/9$7 / 21$.

3. Nandalal, K. D. W., \& Abeyruwan, H.,"An attempt towards wind zone demarcation for Sri Lanka", Proc., Regional Harmonization of Wind Loading and Wind Environmental Specifications in Asia-Pacific Economies (APEC-WW), $6^{\text {th }}$ Workshop, South Korea, 2010.

4. Alnuaimi, A. S., Mohsinb, M.A., \& Al-Riyamic, K.H., "A Basic Wind Speed Map for Oman", the Journal of Engineering Research, 2014, pp. 11(2): 64-78.

5. Lakshmanan, N., Gomathinayagam, S., Harikrishna, P., Abraham, A., \& Ganapathi, S. C., (2009), "Basic wind speed map of India with long-term hourly wind data". Currant Science, 2009, pp.96(7):911-922.

6. Hsu, S. A., "Estimating 3-second and Maximum Instantaneous Gusts from 1-minute Sustained Wind Speeds during a Hurricane", Electronic Journal of Structural Engineering, 2008, pp. 77-79.

7. Panofsky, H. A., \& Dutton, J. A., Atmospheric turbulence: models and methods for engineering applications, Wiley, 1984.
8. McRae, G. J., Goodin,W. R., \& Seinfeld, J. H., "Mathematical modelling of photochemical air pollution", EQL Report No. 18, Environmental Quality Laboratory, Pasadena, California, 1982, pp. 16(4): 679-696.-

9. Harper, B. A., Kepert, J. D., \& Ginger,J.D., Guidelines for converting between various wind averaging periods in tropical cyclone conditions, World Meteorological Organization, 2008, pp. 25.

10. Holmes, J. D. Wind loading of structures, $5^{\text {th }}$ ed., Taylor and Francis, New York, 2007, pp. 29-49. 